\title{
OPTIMIZATION OF POLY-B-HYDROXYBUTYRATE (PHB) PRODUCTION BY AN EGYPTIAN STRAIN OF RHIZOBIUM FABAE F44 USING RESPONSE SURFACE METHODOLOGY
}

\author{
Wafaa $^{1,{ }^{*}}$ H. Radwan, Samah ${ }^{1}$ H. Abu-Hussien, El-Haddad ${ }^{1}$ M.A., \\ Nassef $^{2}$ M.A. and Selim ${ }^{1}$ Sh.M. \\ 1- Agric. Microbiology Dept., Fac. of Agric., Ain Shams Univ., P.O. Box 68, Hadayek Shoubra \\ 11241, Cairo, Egypt \\ 2- Soils, Water and Environ. Res. Inst., Agric. Res. Center, Giza, Egypt. \\ ${ }^{*}$ Corresponding author: wafaahamdy57@yahoo.com
}

Accepted 23 June, 2019

\section{ABSTRACT}

The present work is aimed to isolate, purify, identify a newly isolate Rhizobium fabae from different regions in Egypt then, 58 isolates were obtained from the different 9 governorates with 100 $\%$ infection plant technique. The 16SrRNA showed a similarity of 99.56 (\%) to Rhizobium fabae F44 produce and optimize Poly- $\beta$-Hydroxybutyrate polymer (PHB) production by the selected isolate Rhizobium fabae F44 using a statistical approach of response surface methodology (RSM). Rhizobium fabae F44 isolate was picked up from Sharkia Governorate in Egypt and then identified by the 16SrRNA gene as Rhizobium fabae. Eleven different variables which affect the production of PHB polymer were screened by Plackett-Burman statistical design approach. Maximization of PHB production was adjusted by the terms of The Face Central Composite Design (FCCD) of RSM and assessed at three coded levels $(-1,0,+1)$. One way Anova was used to statistically analyze all obtained results in relation to post hoc multiple comparison analysis performed by Tukey's HSD. Appulses of nutritional and physical factors (two carbon sources, two nitrogen sources, mineral salts, $\mathrm{pH}$, temperature, incubation time, inoculum size and agitation rate) were studied using Plackett-Burman design method. Out of all tested significant media components, sucrose, yeast extract, agitation rate had the highest significant effects on the response as for PHB production, with confidence level $>98 \%$ and were further optimized using FCCD. Predicted Maximum PHB production was observed as $(78.51 \%)$ which in near the mid-
\end{abstract}

point ( 0 ) values (concentrations) of sucrose which reached $(25 \mathrm{~g} / \mathrm{l})$ and yeast extract of $(0.5 \mathrm{~g} / \mathrm{l})$ for 48 $\mathrm{hrs}$. at $150 \mathrm{rpm}$ agitation rate. The observed experimental value reached $87.5 \mathrm{u} / \mathrm{ml}$ was very close result to the predicted one validating the model. So, Response Surface Methodology is an effective statistical approach which can substitute the use of one variable at a time approach due to its adequacy and efficiency to optimize PHB production by Rhizobium fabae F44.

Keywords: Rhizobium sp., Vicia fabaa, Isolation, Production, Optimization, PHB, RSM.

\section{INTRODUCTION}

Grain legumes are highly consumed especially in the poor man nutrition in developing countries diets. Legumes, as known as the poor man's meat, are usually good sources of nutrional foods (Tharanathan and Mahadevamma, 2003 and Pereyra et al 2015). They are cheap and important foundations of proteins, dietary fibers, and starch for a huge section of the world's population, mainly in developing countries.

Faba bean (Vicia faba L.) grain legume has high seed nutritional value so, it is considered as a main feed and food legume crop (Duc et al 2010). In 2010, the biosphere production of faba bean reached 4.0 million tons mostly located in China, Ethiopia, France and Egypt (FAOSTAT, 2013). Mediterranean and Chinese people usage faba bean seeds as dried, green, fresh or canned meals (Bond et al 1985 and Youseifa et al 2014). The educated faba bean area in Egypt has been esti- 
mated as 0.08 million producing about 0.26 million tons (FAOSTAT, 2013).

Rhizobia group are capable of reduction of atmospheric nitrogen $\left(\mathrm{N}_{2}\right)$ to ammonia ( $\mathrm{N}_{2}$-fixation) symbiotically inside legume root nodules contributing about $50 \%$ of the biosphere's available nitrogen (Galloway and Gruber, 2008; Olivares et al 2013). Symbiotic $\mathrm{N}_{2}$-fixing rhizobia comprise a phylogenetically diverse group of bacteria, including both of alpha and beta-proteobacteria, as the genera of Rhizobium, Ensifer (formerly Sinorhizobium), Mesorhizobium, Bradyrhizobium or Azorhizobium (Graham, 2008) in which, the mature bacterial partner housed within the nodule. In return for a source of fixed $\mathrm{N}_{2}$ the plant provides the bacterial partner (the bacteroid) with a supply of carbon source needed in the form of C4-dicarboxylic acids (Lodwig and Poole, 2003 and Monica and Dhingra, 2016).

Poly- $\beta$-Hydroxybutyrate (PHB) is considered as a thermoplastic polymer which synthesized by many bacterial genera such as (Azotobacter beijerinckia, Bacillus megaterium, Ralstonia eutropha, Pseudomonas oleovorans and nitrogen fixing microorganisms originate in root nodules of legume plant family, etc, ). PHB is stored as intracellular mixes and energy storage materials (Hyakutake et al 2011 and Rodriguez-Contreras et al 2013).

(Sangkharak and Prasertsan, 2007 and Muller and Denison, 2018) reported that the most extraordinary characteristic of $\mathrm{P}(3 \mathrm{HB})$ is its biodegradability in several environments. According to its physical properties which are similar to conventional plastics, PHB would be replaced by the use of the conservative plastics to safeguard the environment. However, it is forbidden from use due to the high cost of manufacture compared to artificial plastics.

RSM approach was used firstly by (Box and Wilson, 1951), the aim by checking out the optimum conditions of a group of freelance variables over a particular region of interest during a given system, by establishing between more than one variable and a given response (Haaland, 1990).

Notwithstanding that optimization set up is chosen, RSM wants an oversized variety of experiments. Since an oversized variety of flask media will work on a rotary or orbital shaker, these experiments square measure meted out in shake flasks. (Sankar et al 2010). RSM could be a technique uses a group of mathematical and applied mathematics ways that square measure helpful for modeling and analysis; in experiments wherever a re- sponse of interest is stricken by varied variables and also the aim is to optimize this response.

Isolation of novel high PHB productive strains within the current PHB production strategies could lead to decreasing its production cost. From this point of view, the present study was intended to isolate PHB manufacturing bacteria since the rhizospheric soil of Vicia faba plants and to enhance growth and culture conditions such as temperature, incubation time and $\mathrm{pH}$; and medium conditions (nitrogen and carbon sources) for exploiting PHB production by them using RSM Statistical approach.

\section{MATERIALS AND METHODS}

\section{Bacterial isolation}

Rhizobium isolates were isolated from surfacesterilized origin nodules which were collected from field-grown faba bean from dissimilar sites that represented 9 governorates in Egypt according to (Vincent 1970 and Somasegaran and Hoben 1994). Isolates numbers, geographical locations, and their respective soil characteristics are listed in Table (1).

Table 1. Texture and some physico-chemical characters of soil used for rizobia isolation (Page, 1982).

\begin{tabular}{|c|c|c|c|c|}
\hline $\begin{array}{c}\text { Egypt } \\
\text { Governorate }\end{array}$ & $\begin{array}{c}\text { Number } \\
\text { of } \\
\text { isolates }\end{array}$ & $\begin{array}{c}\text { Soil } \\
\text { texture }\end{array}$ & $\mathrm{pH}$ & $\begin{array}{c}\text { EC } \\
(\mathrm{ds} / \mathrm{m})\end{array}$ \\
\hline Cairo & 8 & Clay soil & 7.84 & 0.472 \\
\hline Giza & 10 & $\begin{array}{c}\text { Sandy } \\
\text { soil }\end{array}$ & 7.42 & 0.579 \\
\hline Qalubia & 11 & Clay soil & 8.46 & 0.273 \\
\hline Gharbya & 15 & $\begin{array}{l}\text { Sandy } \\
\text { soil }\end{array}$ & 7.35 & 0.165 \\
\hline Monofa & 1 & Clay soil & 8.13 & 0.137 \\
\hline Sharkeya & 4 & Clay soil & 7.95 & 0.189 \\
\hline Fayom & 3 & $\begin{array}{l}\text { Sandy } \\
\text { soil }\end{array}$ & 7.21 & 0.674 \\
\hline Beni swef & 2 & Clay soil & 7.83 & 0.128 \\
\hline
\end{tabular}

\section{Maintenance of cultures}

Bacterial cultures were purified by streaking and maintained by subsequent culturing (Somasegaran and Hoben, 1994). Stock culture slants were maintained at $7^{\circ} \mathrm{C}$ yeast extract mannitol medium (YEM) after incubation at $28^{\circ} \mathrm{C}$ for 48 hours. 

of Rhizobium fabae F44 using Response Surface Methodology

\section{Standard inoculum}

Standard inoculum was prepared by inoculation of Erlenmeyer flask containing $100 \mathrm{ml}$ of Yeast Extract Manitol (YEM) broth with a single colony of tested isolate. The inoculated flasks were incubated at $28^{\circ} \mathrm{C}$ for $48 \mathrm{~h}$ on rotary shaker at $150 \mathrm{rpm} .10$ $\mathrm{ml}$ of rhizobial culture were taken aseptically. The optical density (O.D) was to measure at $600 \mathrm{~nm}$. (Girgis and Traore, 2000) Standard cell suspension was prepared for each isolate.

\section{Effect of different carbon and nitrogen sources}

Mannitol and yeast extract of the medium was replaced with different carbon sources (Glucose, Galactose, Dextrose, Fructose, Mannose, Sucrose, Raffinose, Arabinose, Xylose, and Maltose) and nitrogen sources (Peptone, Glycine, Urea and $\mathrm{KNO}_{3}$ ). The amount of carbon and nitrogen compound added was calculated to obtain the same sugar concentration in the original source.

Screening of most significant production parameters by Plackett-Burman design

Screening of most significant production parameters affecting PHB synthesis was studied by Plackett-Burman design. Statistical software package Design-Expert software 11.0.0 (Stat-Ease, Inc., Minneapolis, MN 55413, USA 2018), was used to evaluate the relative importance of physical and nutritional factors for PHB production by the most efficient isolate. A total of $11(n)$ variables including 6 nutritional (2carbon source (A) Mannitol (B) Sucrose, 2 nitrogen source (C) yeast extract (D) glycine, $\mathrm{K}_{2} \mathrm{HPO}_{4}(\mathrm{E})$ and $\mathrm{MgSO}_{4}(\mathrm{~F})$ ) and 5 physical factors $(\mathrm{pH}(\mathrm{G})$, temperature $(\mathrm{H})$, inoculum size $(\mathrm{J})$, incubation period $(\mathrm{K})$ and agitation speed(L)) were studied in $24(n+24 Z)$ experiments as shown in Table (2). (Plackett and Burman, 1946). All the trials were completed in duplicate and the average of observation was castoff as the response of the design. Each variable represented at 2 levels high and low, denoted by $(+)$ and (-) signs, respectively. Each row represented a trial run and each column represented an independent variable.

\section{Central composite design (CCD) and response} surface methodology (RSM)

After identifying the significant variables for PHB production by the most efficient isolates through a Plackett-Burman design a central composite design (CCD) was designed to optimize the significant variables(Sucrose concentration(A), yeast extract $(B)$, agitation $(C)$ and incubution time (D) For Rhizobium fabea. The four selected independent variables were studied at 3 different levels. The statistical software package Design Expert software11.0.0 (Stat-Ease, Inc., Minneapolis, MN 55413, USA 2018).

Table 2. Physico- chemical values for PHB production by Rhizobium fabae isolate as actual code

\begin{tabular}{|c|c|c|c|c|}
\hline Factor & Name & Units & Minimum & Maximum \\
\hline A & Mannitol & $g / l$ & 10.00 & 20.00 \\
\hline B & Sucrose & $g / l$ & 10.00 & 20.00 \\
\hline C & Yeast extract & $g / l$ & 1.00 & 2.00 \\
\hline D & Glycine & $g / l$ & 0.500 & 1.000 \\
\hline$E$ & $\mathrm{~K}_{2} \mathrm{HPO}_{4}$ & $g / l$ & 0.500 & 1.000 \\
\hline $\mathrm{F}$ & $\mathrm{MgSO}_{4}$ & $g / l$ & 0.200 & 0.400 \\
\hline G & $\mathrm{PH}$ & & 6.00 & 8.00 \\
\hline $\mathrm{H}$ & Temperature & ${ }^{\circ} \mathrm{C}$ & 25.00 & 30.00 \\
\hline$J$ & Inoculum size & $\%$ & 3.00 & 7.00 \\
\hline K & $\begin{array}{c}\text { Incubation } \\
\text { time }\end{array}$ & D & 2.00 & 5.00 \\
\hline L & Agitation & $\mathrm{rpm}$ & 150.0 & 200.0 \\
\hline
\end{tabular}

Poly - $\beta$ - hydroxybutyrate accumulation

Determination of the quantity of PHB was performed chemically according to Law and Slepecky (1961) and Kuniko et al (1989).

\section{Molecular identification via 16SrRNA gene}

The most potent isolate was identified by 16SrRNA sequence gene. Isolation of cellular DNA was completed as described by Ausubell et al (1987) and amplification of 16SrRNA was done according to Lane (1991) using the two universal primers ( $\mathrm{F} 1$ : 5, AGAGTTT $(\mathrm{G} / \mathrm{C})$ ATCCTGG CTCAG 3' and R1 5' ACGG (A/C) TACCTTGTTACGACTT 3').

The sequence reads were edited and assem$\begin{array}{lll}\text { bled using BioEditversion 7.0.4 } & \end{array}$ (http://www.mbio.ncsu.edu/BioEdit/bioedit.html)and $\begin{array}{lll}\text { clustal } & W & \text { version }\end{array}$ (http://clustalw.ddbj.nig.ac.jp/top-e.html). BLAST searches were done using the NCBI server atwww.ncbi.nlm.nih.gov/blast/Blast.cgi. Acceding to (Vinnere et al 2002).

\section{Statistical analysis}

The obtained data were statistically analyzed using one-way ANOVA and the Tukey's multiple range tests at a level of significance of $P<0.05$ using Costat program (Version 6.400) according to Snedecor and Cochran (1967). 


\section{RESULTS AND DISCUSSION}

\section{Isolation and authentication of rhizobia}

In the present work, 58 bacterial isolates were isolated from the root nodules of faba bean grown in different localities belonging to 9 Governorates in Egypt. Data presented in Table (3) described the percentage (\%) of rhizobial incidence in different Governorates in Egypt. All isolates were completely purified using YEM medium.

\section{Screening the most efficient PHB production}

Data in Table (4) F14, F26, F28, F44 and F56 represented the most efficient Vicia faba isolates. Among the 5 isolates, the most significant rhizobial isolates, which gave the highest result was F44 for faba bean Rhizobium isolates. F44 was the highest significantly isolate recorded $2.169 \mathrm{~g} / \mathrm{l}, 0.976 \mathrm{~g} / \mathrm{l}$ and $45 \%$ Cell dry weight and contents of cells from $\mathrm{PHB}$ Yield of $\mathrm{PHB} \%$, respectively.

\section{Effect of Carbon and Nitrogen sources for Rhi- zobium F44 isolate}

Data in Table (5) revealed that sucrose was the highest significant carbon sources followed by mannitol and galactose in affecting the PHB production by $\mathrm{F} 44$ isolate, which recorded $2.810 \mathrm{~g} / \mathrm{l}$, $1.042 \mathrm{~g} / \mathrm{l}$, and $37.1 \%$ for cell dry weight, cell content $\mathrm{PHB}$ and yield of $\mathrm{PHB}$, respectively. While Glycine was the highest significant nitrogen sources followed by Yeast extract and $\mathrm{KNO}_{3}$. Which gave $2.585 \mathrm{~g} / \mathrm{l}, 0.997 \mathrm{~g} / \mathrm{l}$, and $38.5 \%$ for cell dry weight, cell content $\mathrm{PHB}$ and yield of PHB, respectively.

Other scientists testified that glucose and fructose, being monosaccharides were readily used by bacteria and, hence, support growth and consequently PHB production, however, the complex molecules like starch and lactose were not exploited for effective PHB production. The current experiments also, the selected Rhizobium isolates did not harvest $\mathrm{PHB}$ on maltose and arabinose indicating that the isolates do not have the enzymes involved in the deprivation of arabinose and maltose into glucose. As the complexity of the carbon source increased, PHB yield was originated to be decreased. Similar conclusions were found by Joshi and Jayaswal (2010).

Mercan et al (2002) investigated the effect of different carbon and nitrogen sources and PHB production in two strains of Rhizobium sp. They noted that the strains fashioned less PHB in yeast extract mannitol (YEM) broth medium with different carbon (sucrose, glucose and arabinose) and nitrogen (L-glycine, L-cysteine, DL-tryptophan, protease peptone and potassium nitrate) sources, while the highest level of PHB accumulation was experimental in the media with L-cysteine and Lglycine.

Maximum PHB synthesis (1.042 $\mathrm{g} / \mathrm{l})$ was found in Rhizobium fabae CCBAU 33202strain. When Sucrose was used as the carbon source (Table 5). The PHB content was lower when glucose, Mannose, and arabinose were used as the carbon sources. Yet, mannitol is generally not preferred in industrial applications as a carbon source due to its higher cost. Therefore, PHB synthesis was assessed in a cheaper and easily originate carbon source that contained Sucrose culture medium instead of mannitol as a carbon source. (Yüksekdağ et al 2003). The other study showed that sucrose contains the maximum level of PHB content (Aslim et al 2002).

Mercan et al (2002) also reported that PHB gathering was high in two strains of Rhizobium sp. when L- cysteine and glycine were secondhand as the nitrogen source. By using potassium nitrate as nitrogen sources Rhizobium produced maximum level of PHB up to (8.6\%). The other study showed that L-cysteine and L-Glycine highest gratified PHB content (Aslim et al 2002).

But the result gotten in this study was in the contrary to the answers of Aslim et al (2002). Bonartseva et al (1994) tested the capacity for PHB production in active and less active strains of $R$. phaseoli, R. meliloti and $R$. trifolii during growth on media with different nitrogen and carbon sources. It was found that PHB amalgamation can be selectively induced whichever in active or less active Rhizobium strains by sources of carbon and nitrogen. They reported that the less active strain of $R$. phaseoli 680 was a promising manufacturer of PHB, and the PHB content in cells of this strain was up to $65 \%$ of dry cell weight during growth on a medium with sucrose and nitrate; the PHB content was much lower when organic acids were used. Based on the temperature Rhizobium produced increased PHB content at $30^{\circ} \mathrm{C}(25 \%)$. The correlation between cell dry weight and PHB content was significant relationship ( $P=1)$.

\section{Statistical experimental designs for evaluation of the factors affecting PHB production}

Rhizobium fabae F44 strain was selected for the optimization of PHB production using a RSM response. Response surface methodology is an 

of Rhizobium fabae F44 using Response Surface Methodology

Table 3. The percentage of rhizobial isolates incidence isolated from Vicia faba plants in 9 different Governorates in Egypt

\begin{tabular}{|l|c|c|c|}
\hline Source of isolates & Number of isolates & Nodulation rate & PHB yield (\%) \\
\hline Behera & 2 & $\% 100$ & $1.9-13.6 \%$ \\
Beni- Swef & 4 & $\% 100$ & $2.9-10.0 \%$ \\
Cairo & 8 & $\% 100$ & $1.6-25.6 \%$ \\
Fayoum & 3 & $\% 100$ & $1.4-26.8 \%$ \\
Gharbya & 15 & $\% 100$ & $1.2-33.9 \%$ \\
Giza & 10 & $\% 100$ & $1.4-28.4 \%$ \\
Monofeya & 1 & $\% 100$ & $2.3 \%$ \\
Qalyobeya & 11 & $\% 100$ & $1.3-33.6 \%$ \\
Sharkeya & 4 & $\% 100$ & $2.0-45.0 \%$ \\
Total & 58 & $1.2-45.0 \%$ \\
\hline
\end{tabular}

Table 4. Cell dry weight, PHB concentration and PHB percentage from the selected rhizobial isolates

\begin{tabular}{|c|l|c|c|c|}
\hline $\begin{array}{c}\text { Strain } \\
\text { No. }\end{array}$ & \multicolumn{1}{|c|}{ Origin of isolates } & $\begin{array}{c}\text { Cell dry } \\
\text { weight (g/l) }\end{array}$ & $\begin{array}{c}\text { Contents of cells from } \\
\text { PHB (g/l) }\end{array}$ & $\begin{array}{c}\text { Yield of } \\
\text { PHB (\%) }\end{array}$ \\
\hline F14 & EL-GharbyaKafferELzayat & $2.002^{\mathrm{d}}$ & $0.529^{\mathrm{d}}$ & $26.4^{\mathrm{e}}$ \\
F26 & EL-fayoum & $1.892^{\mathrm{e}}$ & $0.508^{\mathrm{e}}$ & $26.8^{\mathrm{d}}$ \\
F28 & Al Azhar university & $2.032^{\mathrm{c}}$ & $0.559^{\mathrm{c}}$ & $27.4^{\mathrm{c}}$ \\
F44 & EL-Sharkeya Hehya & $2.169^{\mathrm{a}}$ & $0.976^{\mathrm{a}}$ & $45.0^{\mathrm{a}}$ \\
F56 & Agriculture Research Center & $2.045^{\mathrm{b}}$ & $0.582^{\mathrm{b}}$ & $28.4^{\mathrm{b}}$ \\
\hline
\end{tabular}

*The small letters are for the highly significant factors following a, b, c, d, and e.

* Means within the same column followed by the same letters aren't considerably totally different $(P<0.05)$, according to Duncan's test

Table 5. Effect of different carbon and nitrogen sources on PHB production by Rhizobium fabae F44 isolate for $48 \mathrm{hr}$. at $28^{\circ} \mathrm{C}$

\begin{tabular}{|c|c|c|c|c|}
\hline \multirow{2}{*}{\multicolumn{2}{|c|}{ Nutrition factor }} & \multicolumn{3}{|c|}{ Rhizobium fabae F44 } \\
\hline & & \multirow{2}{*}{$\frac{\text { Yield of PHB (\%) }}{45.0^{\mathrm{a}}}$} & \multirow{2}{*}{$\begin{array}{c}\begin{array}{c}\text { PHB } \\
(\mathbf{g} / \mathbf{l})\end{array} \\
0.976^{\mathrm{b}}\end{array}$} & \multirow{2}{*}{$\begin{array}{c}\begin{array}{c}\text { Dry cell weight } \\
(\mathbf{g} / \mathbf{l})\end{array} \\
2.169^{\mathrm{b}}\end{array}$} \\
\hline \multirow{11}{*}{ 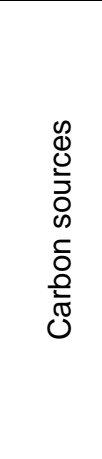 } & Manitol & & & \\
\hline & Glucose & $16.3^{j}$ & $0.339^{f}$ & $2.085^{d}$ \\
\hline & Galactose & $33.2^{\mathrm{C}}$ & $0.703^{c}$ & $2.118^{\mathrm{C}}$ \\
\hline & Dextrose & $25.4^{\mathrm{e}}$ & $0.413^{\mathrm{e}}$ & $1.626^{\mathrm{g}}$ \\
\hline & Fructose & $31.2^{d}$ & $0.530^{d}$ & $1.701^{f}$ \\
\hline & Mannose & $17.5^{\mathrm{h}}$ & $0.269^{j}$ & $1.541^{i}$ \\
\hline & Sucrose & $37.1^{\mathrm{b}}$ & $1.042^{\mathrm{a}}$ & $2.810^{\mathrm{a}}$ \\
\hline & Raffinose & $22.9^{g}$ & $0.311^{\mathrm{h}}$ & $1.361^{\mathrm{h}}$ \\
\hline & Arabinose & $13.4^{\mathrm{k}}$ & $0.209^{k}$ & $1.566^{j}$ \\
\hline & Xylose & $24.8^{f}$ & $0.310^{i}$ & $1.250^{k}$ \\
\hline & Maltose & $16.5^{\mathrm{i}}$ & $0.313^{g}$ & $1.903^{\mathrm{e}}$ \\
\hline \multirow{5}{*}{ 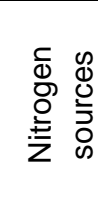 } & Yeast extract & $45.0^{a}$ & $0.976^{b}$ & $2.169^{b}$ \\
\hline & Peptone & $32.5^{c}$ & $0.629^{C}$ & $1.931^{d}$ \\
\hline & Glycine & $38.5^{\mathrm{b}}$ & $0.997^{\mathrm{a}}$ & $2.585^{\mathrm{a}}$ \\
\hline & Urea & $21.2^{\mathrm{e}}$ & $0.331^{\mathrm{e}}$ & $1.558^{\mathrm{e}}$ \\
\hline & $\mathrm{KNO} 3$ & $26.7^{d}$ & $0.520^{d}$ & $1.945^{\mathrm{C}}$ \\
\hline
\end{tabular}

*The small letters are for the highly significant factors following a, b, c, d, e, f, g, h, i, k, and I. * Means within the same column followed by the same letters aren't considerably totally different $(\mathrm{P}<0.05)$, according to Duncan's test 
experimental performance used to evaluate the relationship between set convenient empirical factors and observed consequences. Optimization process included three major steps, execution the statistically designed experiments, determine the constants in a mathematical model and predicting the response and checking the adequacy of the model. The experiments accompanied in the present study were beleaguered toward the construction of the quadratic model for producing Poly- $\beta$ hydroxybutyrate. From the previous nutritional factors experiment, after performing the screening of factors and their interactions, the response surface analysis was carried out, in order to find the optimal conditions for a maximum of Poly- $\beta$ hydroxybutyrate production by selected Rhizobium strain.

\section{Screening of most significant fermentation parameters using Plackett-Burman design}

Plackett-Burman is an efficient way to screen the nutritional and physical factors among a large number of process variables, affecting Poly- $\beta$ hydroxybutyrate production by selected Rhizobium fabae F44 isolate.

Elevn variables including culture conditions $(\mathrm{pH}$, incubation period, inculum size, temperature and agitation speed) nutritional factors (media components), as mannitol, sacrose, yeast extract, glycine, $\mathrm{K}_{2} \mathrm{HPO}_{4}$, and $\mathrm{MgSO}_{4}$ were analyzed by plackett-Burman Design for their effects on PHB production as illustrated in Table (6) and Fig. (1). The design had 24 runs with two levels for each factor. Each variable was examined at two levels: minimum for a low level and maximum for a high level.

Table 6. Plackett-Burman experimental design matrix selection of significant variables of PHB production by Rhizobuim fabae F44 strain

\begin{tabular}{|c|c|c|c|c|c|c|c|c|c|c|c|c|}
\hline Run & $\begin{array}{c}\text { A: } \\
\text { Mannitol } \\
(\mathrm{g} / \mathrm{l}) \\
\end{array}$ & $\begin{array}{c}\text { B: } \\
\text { Sucrose } \\
(g / l) \\
\end{array}$ & \begin{tabular}{|c|} 
C: \\
Yeast \\
extract \\
$(\mathrm{g} / \mathrm{l})$ \\
\end{tabular} & $\begin{array}{c}\text { D: } \\
\text { Glycine } \\
(g / l) \\
\end{array}$ & $\begin{array}{c}\mathrm{E}: \\
\mathrm{K}_{2} \mathrm{HPO}_{4} \\
(\mathrm{~g} / \mathrm{l})\end{array}$ & $\begin{array}{c}\mathrm{F}: \\
\mathrm{MgSO}_{4} \\
(\mathrm{~g} / \mathrm{l}) \\
\end{array}$ & $\begin{array}{l}\text { G: } \\
\text { PH }\end{array}$ & $\begin{array}{c}\mathrm{H}: \\
\text { temperature } \\
\left({ }^{\circ} \mathrm{C}\right) \\
\end{array}$ & \begin{tabular}{|c|}
$\mathrm{J}:$ \\
Inoculum \\
size \\
$(\%)$ \\
\end{tabular} & $\begin{array}{c}\mathrm{K}: \\
\text { Incubation } \\
\text { time } \\
\text { (D) }\end{array}$ & $\begin{array}{c}\text { L: } \\
\text { Agitation } \\
\text { (rpm) } \\
\end{array}$ & $\begin{array}{c}\text { PHB } \\
\text { yield } \\
(\%) \\
\end{array}$ \\
\hline 1 & 20 & 20 & 1.0 & 0.5 & 0.5 & 0.4 & 6 & 30 & 7.0 & 2 & 200 & 58.55 \\
\hline 2 & 10 & 10 & 1.0 & 0.5 & 0.5 & 0.2 & 6 & 25 & 3.0 & 2 & 150 & 27.22 \\
\hline 3 & 20 & 20 & 2.0 & 0.5 & 0.5 & 0.2 & 8 & 25 & 7.0 & 5 & 150 & 60.44 \\
\hline 4 & 10 & 20 & 1.0 & 1.0 & 1.0 & 0.2 & 8 & 30 & 7.0 & 2 & 150 & 29.86 \\
\hline 5 & 10 & 10 & 1.0 & 1.0 & 0.5 & 0.4 & 8 & 25 & 7.0 & 5 & 200 & 56.81 \\
\hline 6 & 10 & 20 & 2.0 & 1.0 & 0.5 & 0.2 & 6 & 30 & 3.0 & 5 & 200 & 22.83 \\
\hline 7 & 20 & 10 & 2.0 & 1.0 & 0.5 & 0.4 & 8 & 30 & 3.0 & 2 & 150 & 52.40 \\
\hline 8 & 10 & 10 & 2.0 & 0.5 & 1.0 & 0.4 & 6 & 30 & 7.0 & 5 & 150 & 64.31 \\
\hline 9 & 20 & 10 & 2.0 & 1.0 & 1.0 & 0.2 & 6 & 25 & 7.0 & 2 & 200 & 60.44 \\
\hline 10 & 20 & 20 & 1.0 & 1.0 & 1.0 & 0.4 & 6 & 25 & 3.0 & 5 & 150 & 29.86 \\
\hline 11 & 10 & 20 & 2.0 & 0.5 & 1.0 & 0.4 & 8 & 25 & 3.0 & 2 & 200 & 46.86 \\
\hline 12 & 20 & 10 & 1.0 & 0.5 & 1.0 & 0.2 & 8 & 30 & 3.0 & 5 & 200 & 28.82 \\
\hline 13 & 10 & 10 & 2.0 & 1.0 & 1.0 & 0.2 & 8 & 25 & 3.0 & 5 & 150 & 25.94 \\
\hline 14 & 10 & 10 & 1.0 & 1.0 & 1.0 & 0.4 & 6 & 30 & 3.0 & 2 & 200 & 47.95 \\
\hline 15 & 20 & 20 & 1.0 & 1.0 & 0.5 & 0.2 & 8 & 25 & 3.0 & 2 & 200 & 65.21 \\
\hline 16 & 10 & 20 & 2.0 & 1.0 & 0.5 & 0.4 & 6 & 25 & 7.0 & 2 & 150 & 31.56 \\
\hline 17 & 20 & 10 & 2.0 & 0.5 & 0.5 & 0.4 & 6 & 25 & 3.0 & 5 & 200 & 25.94 \\
\hline 18 & 10 & 20 & 1.0 & 0.5 & 1.0 & 0.2 & 6 & 25 & 7.0 & 5 & 200 & 23.76 \\
\hline 19 & 20 & 10 & 1.0 & 1.0 & 0.5 & 0.2 & 6 & 30 & 7.0 & 5 & 150 & 65.99 \\
\hline 20 & 20 & 20 & 2.0 & 0.5 & 1.0 & 0.2 & 6 & 30 & 3.0 & 2 & 150 & 51.58 \\
\hline 21 & 10 & 10 & 2.0 & 0.5 & 0.5 & 0.2 & 8 & 30 & 7.0 & 2 & 200 & 45.78 \\
\hline 22 & 10 & 20 & 1.0 & 0.5 & 0.5 & 0.4 & 8 & 30 & 3.0 & 5 & 150 & 43.66 \\
\hline 23 & 20 & 10 & 1.0 & 0.5 & 1.0 & 0.4 & 8 & 25 & 7.0 & 2 & 150 & 47.95 \\
\hline 24 & 20 & 20 & 2.0 & 1.0 & 1.0 & 0.4 & 8 & 30 & 3.0 & 5 & 200 & 29.31 \\
\hline
\end{tabular}




\section{Optimization of Poly- $\beta$-Hydroxybutyrate (PHB) Production by an Egyptian strain of Rhizobium fabae F44 using Response Surface Methodology}

The statistical design approach using RSM was used to study the individual and interactive effects of various process parameters on PHB production by Rhizobuim fabae F44 isolate. The ranges of the independent process variables were selected based on previous studies described by Grothe et al (1999).

For Rhizobuim fabae F44 isolate Statistical analysis of variance ANOVA one way of PlackettBurman design for PHB production by Rhizobuim fabae showed that "Model F-value" of $10.92 \mathrm{im}$ plies the model is significant. P-values less than 0.0500 indicate model terms are significant. In this case B (Sucrose), C (Yeast extract), K (Incubation time) and, $L$ (Agitation) are significant model terms. The variables, evidencing statistically effects, were screened. Factors, evidencing values of (prob.>) $\mathrm{F}$ less than 0.05 , were considered to have significant belongings on the response and they were Sucrose $(B)$, yeast extract $(C)$, incubation time $(K)$ and agitation $(\mathrm{L})$. From the analysis of the values of the regression coefficients of all the factors, it was found that all of them had a positive effect on PHB production. But on the basis of percentage contribution, it was found that the contribution of $\mathrm{pH}$ was negligible. Therefore, this ingredient was avoided by the media in the next step of optimization.
Among the significant media components, Sucrose $(B)$, yeast extract $(\mathrm{C})$, incubation time $(\mathrm{K})$ and agitation (L), with confidence level 95\% were further optimized using FCCCD.

The final equation in footings of coded factors can be secondhand to make predictions about the answer for given levels of all factor. By default, the high levels of the factors are coded as +1 and the low levels are coded as -1 . The coded equation is valuable four identifying the comparative impact of the factors by associating the factor coefficients.

The final equation in terms of oblique factors can be used to brand predictions about the answer for given levels of each factor. By avoidance, the high levels of the factors are coded as +1 and the low levels are coded as -1 . The coded equation is useful four identifying the relative impact of the factors by comparing the factor coefficients.

$\mathbf{Y}_{\mathrm{PHB}}=43.85+2.36$ (Mannitol) +5.86 (Sucrose) + 5.57 (Yeast extract) - 1.33( $\left.\mathrm{K}_{2} \mathrm{HPO}_{4}\right)-1.02\left(\mathrm{MgSO}_{4}\right)$ $+1.44(\mathrm{pH})+2.39$ (Temperature) -2.51 (Inoculum size)- 3.74 (Incubation time) +2.90 (Agitation) + 4.89(Mannitol * Sucrose) - 2.88(Mannitol ${ }^{*}$ $\left.\mathrm{K}_{2} \mathrm{HPO}_{4}\right)+4.89$ (Mannitol* $\left.{ }^{*} \mathrm{MSO}_{4}\right)-2.03$ (Mannitol * Temperature) -3.16 (Mannitol* Inoculum size) - 7.45 (Mannitol * Agitation)
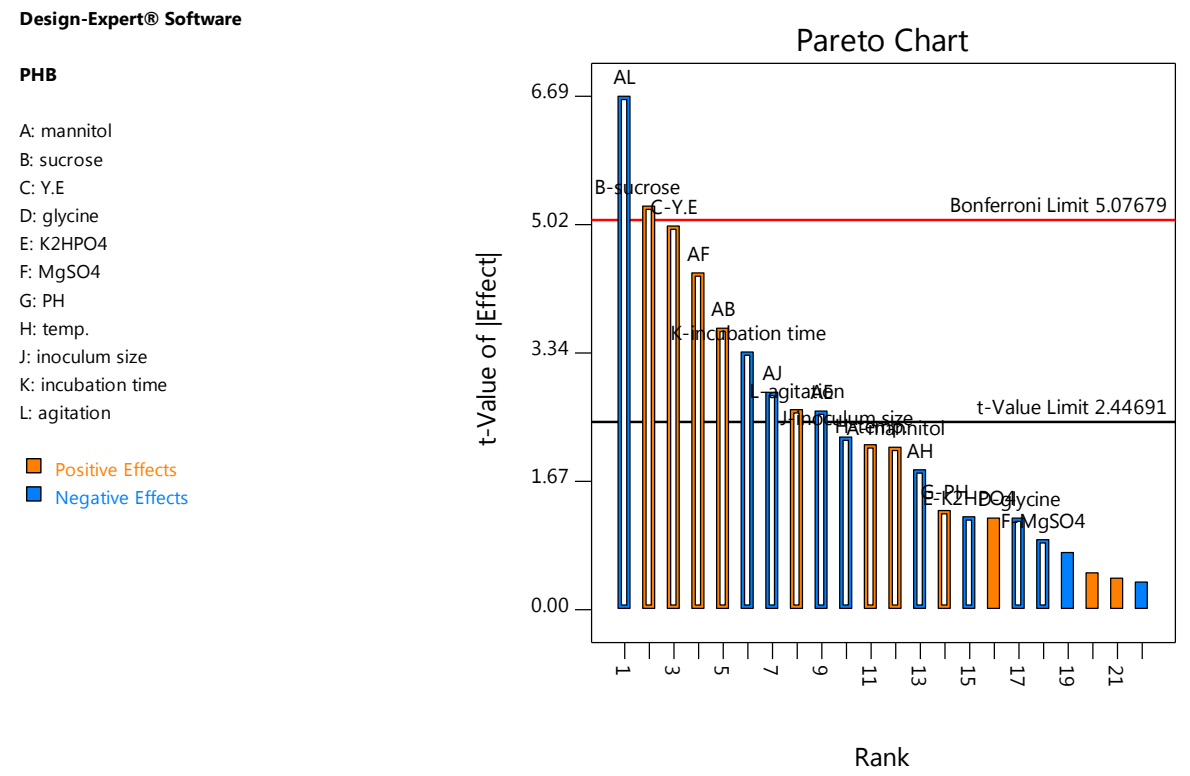

Fig. 1. Pareto graph showing contribution effect (\%) of different variables on PHB production by Rhizobuim fabae F44 based on the observation of Plackett-Burman design (the orange color represents positive effects and the blue color represents negative effects). 
Run 19 was the best run with the highest yield of $\mathrm{PHB}$ which reached $65.99 \%$, it contains $20 \mathrm{~g} / \mathrm{l}$ mannitol, $10 \mathrm{~g} / \mathrm{l}$ sucrose, $1 \mathrm{~g} / \mathrm{l}$ yeast extract, $1 \mathrm{~g} / \mathrm{l}$ glycerin, $0.5 \mathrm{~g} / \mathrm{l} \mathrm{K} \mathrm{HPO}_{4}$ and $0.2 \mathrm{~g} / \mathrm{l} \mathrm{MgSO}_{4}, \mathrm{PH} 6$, $7 \%$ inoculum size, with agitation $150 \mathrm{rpm}$ raced and incubated for 4 days at $30^{\circ} \mathrm{C}$ where production multiplied 1.46 times from production in the basic medium(with conditions $\mathrm{K}_{2} \mathrm{HPO}_{4} \quad(0.5) \mathrm{g} / \mathrm{l}$, $\mathrm{MgSO}_{4} .7 \mathrm{H}_{2} \mathrm{O}(0.2) \mathrm{g} / \mathrm{l}, \mathrm{NaCl}(0.1) \mathrm{g} / \mathrm{l}$, Mannitol (10.0) $\mathrm{g} / \mathrm{l}$, Yeast extract (1.0) $\mathrm{g} / \mathrm{l}$ and $\mathrm{pH}(7.0)$ ).

For maximum PHB production, it is important to assess the physiological and environmental factors of the bacterial isolates under examination for the PHB production process. PHB production appears to be due to the effect of initial $\mathrm{pH}$ on the bioavailability of suggestion elements (Ramadas et al 2009). Flora et al (2010) revealed that the maximum PHB production (65.99\%) by Rhizobium fabae $\mathrm{F} 44$ strain was at $\mathrm{pH}$ range from 6.5-6.0, and the reduction of polymer accumulation at advanced $\mathrm{pH}$ values are due to the effect on the derivative enzymes of polymer breakdown so that $\mathrm{PHB}$ is utilized at a rate almost equivalent to the rate of its synthesis. The influence of $\mathrm{pH}$ of culture media on PHB manufacture was also optimized then highest production was gotten at a $\mathrm{pH}$ range of 7.0. The obtained consequences $(\mathrm{pH})$ were in agreement with Aslim et al (2002) who also observed that the $\mathrm{PHB}$ in Rhizobium sp. strain produced was maximum at $\mathrm{pH}$ 7.0. Grothe et al (1999) also described that $\mathrm{pH}$ value ranging from $6.0-7.5$ is optimum aimed at PHB production. However, contrary to these, Nakata (1963) described that PHB production occurs at $\mathrm{pH}$ of 6.4 in addition that the lack of polymer accumulation at higher $\mathrm{pH}$ value can best be elucidated by an effect on the degenerative enzymes of polymer breakdown, so that the PHB is employed at the rate almost equal to the rate of its synthesis.

Effect of Inoculum Size Results revealed that maximum PHB output (65.99\%) was achieved by Rhizobium fabae $\mathrm{F} 44$, with $7 \mathrm{ml}$ inoculum level/flask; however, minimal PHB contents (29.3\%) were achieved by Rhizobium fabae F44 strain with $3 \mathrm{ml}$ inoculum level/flask. Accordingly, $7 \mathrm{ml} / 100 \mathrm{ml}$ inoculum level was selected to carry out the next part of the research. Low inoculum size essential a longer time for cells to reproduce and produce the desired product (Jiff et al 1998). A small amount of inoculum can lead to an inadequate number of microbial cells and a reduced quantity of the secreted enzymes while a much higher inoculum might lead to or cause a lack of oxygen and reduc- tion of nutrients in the culture media (Abusham et al 2009).

Results indicated that maximum PHB production was attained at $30^{\circ} \mathrm{C}$ incubation temperature. Higher or lower temperatures showed inferior results. Tamodgan and Sidal (2011) reported that higher and lower temperatures than $30^{\circ} \mathrm{C}$ lead to decrease in PHB synthesis by Bacillus subtilis ATCC 6633, as well as cell mass, probably due to the activity of the low enzyme.

In the present study, $\mathrm{KH}_{2} \mathrm{PO}_{4}$ supplied as phosphorus sources seemed to have a positive effect on $\mathrm{PHB}$ production in their high levels at 0.05 $\mathrm{g} / 100 \mathrm{ml}$ and $0.1 \mathrm{~g} / 100 \mathrm{ml}$ respectively. A phosphorous limiting disorder in the presence of $\mathrm{KH}_{2} \mathrm{PO}_{4}$ and $\mathrm{K}_{2} \mathrm{HPO}_{4}$ was an important factor for $\mathrm{PHB}$ production (Sangkharak and Prasertan, 2007).

Optimization of physical and nutritional factors using Face Centered Central Composite Design (FCCCD) of Response Surface Methodology (RSM)

\section{Optimization of PHB production by Rhizobium fabae F44.}

After selecting the most significant variables influencing PHB production by Rhizobium fabae F44 showing confidence level 95 - 99\% using PlackettBurman design, a central composite design (CCD) was performed to determine the optimal levels and the interactions among the selected significant variables. In this study, a total of 30 experiments with different combination of Sucrose concentration (A), Yeast extract concentration (B), Agitation (C), and incubution time (D) were performed and the results of experiments for studying the effects of four independent variables on PHB production at three different levels coded as $-1,0$, and +1 are presented along with actual and predicted response Table (7). The data showed great variation in the PHB production. Run numbers $8,11,13,21$ and 19 showed a high PHB content $(\geq 61.11 \%)$.

The maximum production $(78.51 \%)$ was achieved at run number 19 in the presence of 25 $\mathrm{g} / \mathrm{l}$ sucrose, $0.5 \mathrm{~g} / \mathrm{l}$ yeast extract, $150 \mathrm{rpm}$ and an incubation time of 2 day, while the minimum production $(78.51 \%)$. The lowest production was recoded in run numbers 2 and 12 for F44 isolate. The statistical significance of the model was checked by F-test and ANOVA aimed at the response surface quadratic model are summarized. The model F-value of 3.98 indirect the model was significant. 

of Rhizobium fabae F44 using Response Surface Methodology

A p-value was also less than 0.05 demonstrate the model was highly significant and indicating that there was only a $0.01 \%$ chance that a "Model FValue" this large might occur due to noise.

The determination coefficient $R^{2}$ of the model was 0.97 for PHB production, indicated that $97 \%$ of the total variations were explained by the model and revealed good agreement between the experimental results and the predicted values calculated from the model. Therefore, the present $R^{2}$ value hinted that the model is reliable for PHB production in the present study.
The final equation in terms of actual factors can be secondhand to make predictions about the response for given levels of each factor. Here, the levels should be quantified in the original units aimed at each factor. This equation should not be used to control the relative impact of all factor because the coefficients are scaled to house the units of each factor and the intercept is not at the center of the design space.

$\mathrm{Y}_{\mathrm{PHB}}=23.192+1.51517$ (Sucrose) +1.0683 (yeast extract) -0.0755 (agitation) +3.402 incubation time)

Where the $\mathrm{Y}$ is the predicted response

Table 7. Central composite desing CCD of independent variables for PHB prodaction by Rhizobium fabae F44 isolate

\begin{tabular}{|c|c|c|c|c|c|}
\hline Run & $\begin{array}{c}\text { Factor 1 } \\
\text { A. Sucrose } \\
\text { (g/l) }\end{array}$ & $\begin{array}{c}\text { Factor 2 } \\
\text { B. yeast extract } \\
(\mathbf{g} / \mathbf{l})\end{array}$ & $\begin{array}{c}\text { Factor 3 } \\
\text { C.agitation } \\
\text { (rpm) }\end{array}$ & $\begin{array}{c}\text { Factor 4 } \\
\text { D. incubution tiem } \\
\text { (D) }\end{array}$ & $\begin{array}{c}\text { Response 1 } \\
\text { PHB } \\
(\%)\end{array}$ \\
\hline 1 & 20 & 1.0 & 185 & 3 & 56.86 \\
2 & 20 & 1.0 & 255 & 3 & 29.99 \\
3 & 25 & 1.5 & 220 & 2 & 53.09 \\
4 & 25 & 0.5 & 220 & 2 & 46.63 \\
5 & 25 & 0.5 & 150 & 4 & 57.23 \\
6 & 15 & 1.5 & 150 & 2 & 35.41 \\
7 & 20 & 1.0 & 185 & 3 & 54.56 \\
8 & 25 & 1.5 & 220 & 4 & 69.95 \\
9 & 15 & 1.5 & 220 & 2 & 34.58 \\
10 & 20 & 1.0 & 185 & 3 & 58.63 \\
11 & 20 & 1.0 & 185 & 3 & 64.15 \\
12 & 10 & 1.0 & 185 & 3 & 26.83 \\
13 & 30 & 1.0 & 185 & 3 & 72.73 \\
14 & 15 & 0.5 & 220 & 2 & 34.93 \\
15 & 20 & 1.0 & 185 & 3 & 59.56 \\
16 & 15 & 0.5 & 150 & 2 & 50.25 \\
17 & 20 & 2.0 & 185 & 3 & 45.84 \\
18 & 25 & 1.5 & 150 & 2 & 51.52 \\
19 & 25 & 0.5 & 150 & 2 & 78.51 \\
20 & 15 & 1.5 & 220 & 4 & 58.41 \\
21 & 25 & 0.5 & 220 & 4 & 61.11 \\
22 & 20 & 1.0 & 185 & 1 & 50.44 \\
23 & 15 & 1.5 & 150 & 4 & 58.09 \\
24 & 20 & 1.0 & 185 & 3 & 42.21 \\
25 & 20 & 1.0 & 115 & 3 & 39.22 \\
26 & 20 & 00 & 185 & 3 & 27.45 \\
27 & 25 & 1.5 & 150 & 4 & 53.33 \\
28 & 20 & 1.0 & 185 & 5 & 56.74 \\
29 & 15 & 0.5 & 220 & 4 & 45.19 \\
30 & 15 & 0.5 & 150 & 4 & 57.59 \\
\hline & & & & & \\
\hline
\end{tabular}


Three-dimensional response surface and twodimensional contour plots are graphical based on the model equation to explain the interaction among variables and to determine the optimum level of each factor for PHB production Fig. (2).
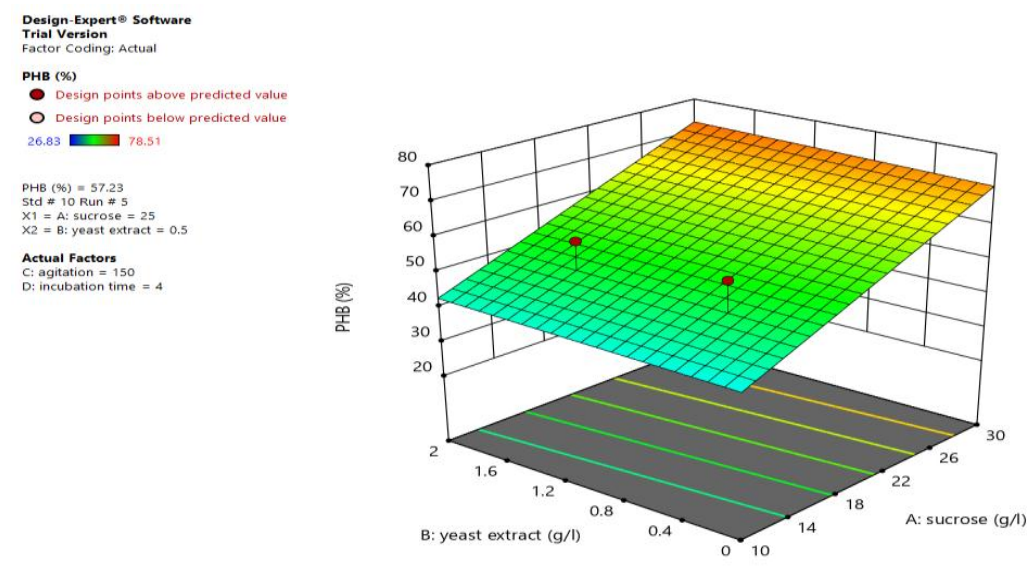

Fig. 2. Three-dimensional response surface showing the effect of sucrose concentration, Yeast extract concentration and incubation time and their mutual effect on the PHB production

Pozo et al (2002) studied the effects of culture circumstances on PHB production by Azotobacter $s p$. and showed that growth conditions counting $\mathrm{pH}$, temperature theaters an important role in the production degree of PHB. The PHA production by a specific strain also related to its biomass. As the biomass upsurges the bacteria also starts accumulating $\mathrm{PHB}$ and produce maximum PHB when its biomass is at its peak equal and PHB production is slowed depressed as the biomass is dropped because at this phase of the growth all the nutrients are depleted leading to decrease in PHB content.

Identification of the most efficient bacteria by amplification and sequencing of 16S $r$ RNA of isolates F44

These rhizobial isolates were chosen for further identification using phylogenetic analysis of $16 \mathrm{~S}$ $r$ RNA gene sequences. Based on morphological physiological characteristics, Gram staining, and further confirmation by sequencing the 16SrRNA gene, the isolates F44 was identified as Rhizobium fabae. Upon the amplification of 16S $r$ RNA sequence, using universal primer, an amplified product of 1347bp Fig. (3) was obtained, sequenced and compared with the Gen Bank databases using BLASTN software by the Finch TV program (http://www.geospiza.com/Products/finchtv.sht $\mathrm{ml}$ ). The $16 \mathrm{SrRNA}$ sequence of the isolate $\mathrm{F} 44$ revealed a close relatedness to Rhizobium fabae with $99.56 \%$ similarity in Table (8). The phylogenetic analysis of nucleotide sequences on the basis of $16 \mathrm{Sr}$ RNA revealed most closely to Rhizobium fabae Fig. (4). Hence the strain was confirmed as Rhizobium fabae and the sequence was submitted to Gen Bank. 

of Rhizobium fabae F44 using Response Surface Methodology

CACATGCAAGTCGAGCGCCCCGCAAGGGGAGCGGCAGACGGGTGAGTAACGCGTGGGAACG
TACCCTTTACTACGGAATAACGCAGGGAAACTTGTGCTAATACCGTATGTGCCCTTAGGGGGAAA
GATTTATCGGTAAAGGATCGGCCCGCGTTGGATTAGCTAGTTGGTGGGGTAAAGGCCTACCAAG
GCGACGATCCATAGCTGGTCTGAGAGGATGATCAGCCACATTGGGACTGAGACACGGCCCAAA
CTCCTACGGGAGGCAGCAGTGGGAATATTGACAATGGGGCAAGCCTGATCCAGCCATGCC
GCGTGAGTGATGAAGGCCTAGGGTTGAAAGCTCTTTCACCGGAGAAGATAATGACGGTATCC
GGAGAAGAACCCCGCTAACTTCGTGCCAGCAGCCGCGGTAATACGAAGGGGGCTAGCGTTGT
TCGGAATTACTGGGCGTAAAGCGCACGTAGGCGGATCGATCAGTCAGGGGTGAAATCCCAGGG
CTCAACCCTGGAACTGCCTTTGATACTGTCGATCTGGAGTATGGAAGAGGTGAGTGGAATTCCGA
GTGTAGAGGTGAATTCGTAGATATTCGGAGGAACACCAGTGGCGAAGGCGGCTCACTGGTCCA
TTACTGACGCTGAGGTGCGAAAGGTGGGGACAAACAGGATTAGATACCCTGGTAGTCCACGC
CGTAAACGATGAATGTTAGCCGTCGGGCAGTATACTGTTCGGTGGCGCAGCTAACGCATTAAAC
ATTCCGCCTGGGGAGTACGGTCGCAAGATAACTCAAAGGAATTGACGGGGGCCCGCACAAGCG
GTGGAGCATGTGGTTTAATTCGAAGCAACGCGCAGACCTTACCAGCCCTTGACATGCCCGGCTA
CTTGCAGAGATGCAAGGTTCCCTTCGGGGACCGGGACACAGGTGCTGCATGGCTGTCGTCAGC
TCGTGTCGTGAGATGTTGGTTAAGTCCCGCAACGAGCGCAACCCTCGCCCTTAGTTGCCAGCA
TTCAGTTGGGCACTCTAAGGGGACTGCCGGTGATAAGCCGAGAGGAAGGGGGGATGACGTCA
AGTCCTCATGGCCCTTACGGCTGGGCTACACACGTGCTACAATGGTGGTGACAGTGGGCAGCGA
GCACGCGAGTGTGAGCTAATCTCCAAAAGCCATCTCAGTTCGGATTGCACTCTGCAACTCG AGT
GCATGAAGTTGGAATCGCTAGTAATCGCGGATCAGCATGCCGCGGTGAATACGTTCCCGGGCC
TTGTACACACCGCCCGTCACACCATGGGAGTTGGTTTTACCCGAAGGTAGTGCGCTAACCGCA
AGGAGGCAGCTAA

Fig. 3. Partial nucleotide sequence (1347 nts) of 16 SrRNA of Rhizobium F44 isolate.

Table 8. Sequences producing significant alignments of partial sequence of 16SrRNA of Rhizobium F44 isolate with E-value (0.0).

\begin{tabular}{|l|c|c|}
\hline \multicolumn{1}{|c|}{ Description } & $\begin{array}{c}\text { Per. Identities } \\
(\%)\end{array}$ & Accession \\
\hline $\begin{array}{l}\text { Rhizobium etli strain WzP15 16S ribosomal RNA gene, partial sequence } \\
\text { Rhizobium fabae strain CCBAU 33202 16S ribosomal RNA, partial se- } \\
\text { quence }\end{array}$ 99.56\% & EU637928.1 \\
Rhizobium etli strain WzP15 16S ribosomal RNA gene, partial sequence & $99.56 \%$ & EU_115872.1 \\
Rhizobium fabae strain CCBAU 33202 16S ribosomal RNA, partial se- & $99.56 \%$ & NR_115872.1 \\
quence & $99.48 \%$ & KY971003.1 \\
Rhizobium sp. strain CPAO 5.2F 16S ribosomal RNA gene, partial sequence & $99.48 \%$ & KX130602.1 \\
Rhizobium fabae strain MJT 16S ribosomal RNA gene, partial sequence & KX226364.1 \\
Rhizobium leguminosarum strain PM1 16S ribosomal RNA gene, partial & $99.48 \%$ & \\
sequence & & KX226364.1 \\
Rhizobium leguminosarum strain PM1 16S ribosomal RNA gene, partial & $99.48 \%$ & \\
sequence & & KP209443.1 \\
Rhizobium leguminosarum strain EB33 16S ribosomal RNA gene, partial & $99.48 \%$ & \\
sequence & & AB680659.1 \\
Rhizobium leguminosarum gene for 16S rRNA, partial sequence, strain: & $99.48 \%$ \\
NBRC 14778 & $99.48 \%$ & AY117632.1 \\
Rhizobium etli strain PRF76 16S ribosomal RNA gene, complete sequence & AY117630.1 \\
Rhizobium etli strain PRF230 16S ribosomal RNA gene, complete sequence & $99.48 \%$ & NR_115253.1 \\
Rhizobium pisi strain DSM 30132 16S ribosomal RNA, partial sequence & $99.48 \%$ \\
Rhizobium etli strain RP320 16S ribosomal RNA gene, partial sequence & $99.41 \%$ & DQ406702.1 \\
\hline
\end{tabular}




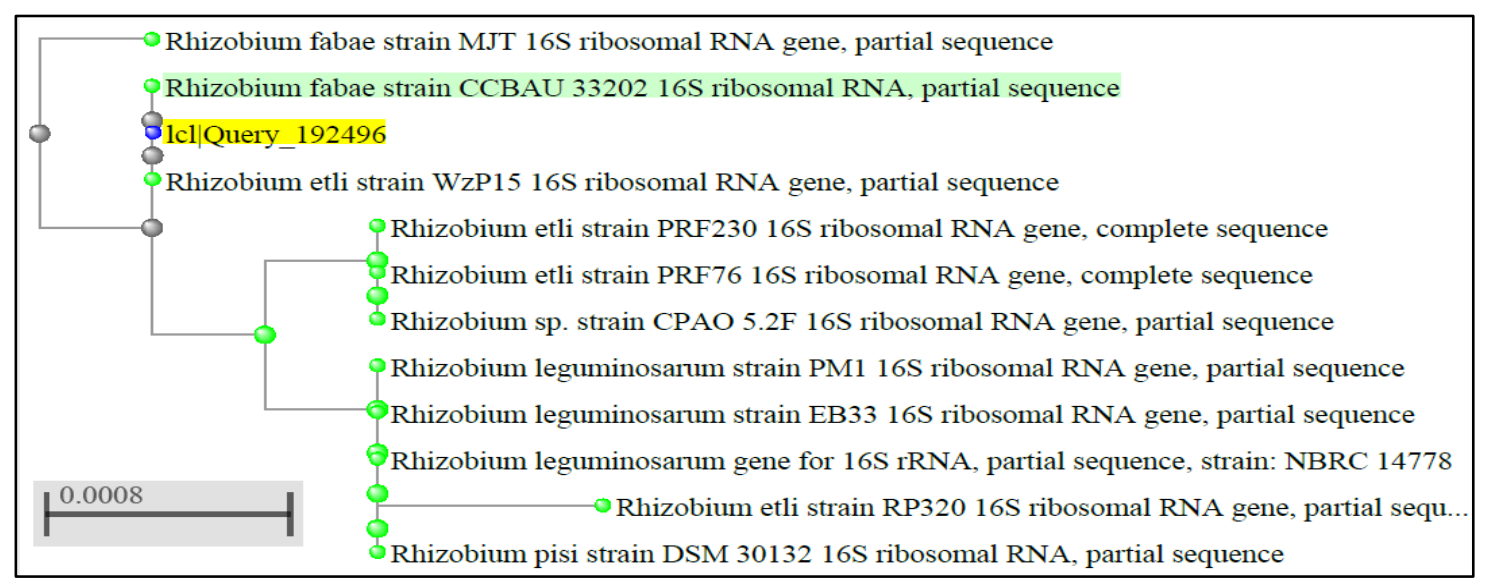

Fig. 4. Phylogenetic tree of partial sequence of 16 SrRNA of Rhizobium F44 isolate compared to 12 Rhizobium strains recorded in GenBank.

\section{CONCLUSION}

From the previous results, it was concluded that the optimal levels of the process variables for maximum concentration of PHB by Rhizobium fabae are in medium containing $25 \mathrm{~g} / \mathrm{l}$ Sucrose, 0.5 $\mathrm{g} / \mathrm{l}$ yeast extract, $05 \mathrm{~g} / \mathrm{K} \mathrm{K}_{2} \mathrm{HPO}_{4}, 0.2 \mathrm{~g} / \mathrm{l} \mathrm{MgSO}$, 0.1 $\mathrm{g} / \mathrm{l} \mathrm{NaCl}, 7 \mathrm{pH}$, at $30^{\circ} \mathrm{C}, 7 \mathrm{ml}$ inoculum size, 150 rpm for $48 \mathrm{hrs}$. incubation time.

\section{REFERENCES}

Abusham R., Raja N., Rahman R., Abu B. and Mahiran B. 2009. Optimization of physical factors affecting the production of thermo-stable organic solvent-tolerant protease from a newly isolated halo tolerant Bacillus subtilis strain Rand. Microb. Cell Fact., 8, 20-28.

Aslim B., Yuksekdag Z.N. and Beyatli Y. 2002. Determination of PHB growth quantities of certain Bacillus species isolated from soil. Turk. E.J. Biotechnol., 2, 24-30.

Ausubel L.M. and Deneckere R.J. 1987. One is almost enough for monopoly. The Rand J. Econom., 3, 255-274.

Bonartseva G.A., Myshkina V.L. and Zagreba E.D. 1994. Poly- $\beta$-hydroxybutyrate content in cells of various Rhizobium species during growth with different carbon and nitrogen source. Microbiol., 63(1), 45-48.

Bond D.A., Lawes D.A., Hawtin G.C., Saxena M.C. and Stephens J.S. 1985. Fababean (Vicia faba L.). In: Grain Legume Crops, Summer- field R.J. and Roberts E.H. (eds.), William Collins Sons Co. Ltd., London, pp. 199-265.

Box G.E.P. and Wilson K.B. 1951. On the experimental attainment of optimum conditions. J. Royal Statist. Soc., 13, 1-45.

Duc G., Bao S., Baum M., Redden B., Sadiki M., Suso M.J., Vishniakova $M$. and Zong $X$. 2010. Diversity maintenance and use of Vicia faba L. genetic resources. Field Crops Res., 115, 270-278.

FAOSTAT, 2013. Statistical Database of the Food and Agricultural Organization of the United $\mathrm{Na}$ tions, Roma, Italy. (http://faostat3.fao.org/browse/Q/QC/E)

Flora G., Bhatt K. and Tuteja U. 2010. Optimization of Culture Conditions Poly Â-Hydroxybutyrate Production From isolated Bacillus Species. J. Cell Tissue Res., 10, 2235-2242.

Galloway J. and Gruber N. 2008. An Earthsystem Perspective of the Global Nitrogen Cycle. Nature. 451, 293-296.

Girgis M.G.Z. and Traoré A.S. 2000. Use of streptomycin resistance and production of exopolysaccharides as markers in competition studies with cowpea Bradyrhizobia. Annals. Agric. Sci., Fac. of Agric., Ain Shams Univ., Cairo, 45, 385-407.

Graham P. 2008. Ecology of Root-Nodule Bacteria of Legumes. In: "Nitrogen-Fixing Leguminous Symbioses", Dilworth M., James E. Sprent J. and Newton W. (eds.). The Netherlands: Springer. pp. 23-43. 

of Rhizobium fabae F44 using Response Surface Methodology

Grothe E., Moo-Young M. and Chisti Y. 1999. "Fermentation optimization for the production of poly ( $\beta$-hydroxybutyric acid) microbial thermoplastic," Enzyme and Microbial Technol., 25(1-2), 132-141.

Haaland P.D. 1990. Separating signals from noise. In: Experimental Design in Biotechnology. pp. 61-83. New York: Marcel Dekker, USA.

Hyakutake M., Saito Y., Tomizawa S., Mizuno K. and Tsuge T. 2011. Polyhydroxyalkanoate (PHA) synthesis by class IV PHA synthases employing Ralstonia eutropha $\mathrm{PH} 44$ as host strain. 75(8), 1615-1617.

Jiff B., Van leeuwen J. Patel B. and Yu Q. 1998. Utilization of starch processing wastewater for production of biomass protein and fungal aamylase by Aspergillus oryzae. Biores. Technol., 66, 201-206.

Joshi P.A. and Jaysawal S.R. 2010. Isolation and characterization of poly-B-hydroxyalkanoate producing bacteria from sewage sample. J. Cell and Tissue Res.., 10(1), 2165-2168.

Kuniko M., Nakamura Y. and Doi Y. 1989. New bacterial copolyesters produced in Alcaligenes eutrophus from organic acids. Polymer Commun., 29, 174-176.

Lane D.J. 1991. "16S/23S r RNA sequencing. In Nucleic acid Techniques in Bacterial Systematics". Stackebrandt E. and Goodfellow M. (eds.) pp. 115-175.

Law J.H. and Slepecky R.A. 1961. Assay of poly$\beta$-hydroxybutyric acid. J. Bacteriol., 82, 33-36.

Lodwig E. and Poole P. 2003. Metabolism of Rhizobium Bacteroids. Critical Rev. Plant Sci., 22, 37-78.

Mercan N., Aslım B., Yüksekdağ Z.N. and Beyatlı Y. 2002. Production of poly- $\beta$ hydroxybutyrate (PHB) by some Rhizobium bacteria. Turk J. Biol., 26, 215-219.

Monika S. and Dhingra H.K. 2016. Poly- $\beta-$ hydroxybutyrate: A Biodegradable Polyester, Biosynthesis and Biodegradation. British Microbiol. Res. J., 14(3), 1-11.

Muller K.E. and Denison F.R. 2018. Resource acquisition and allocation traits in symbiotic rhizobia with implications for life history outside of legume hosts. R. Soc. Open Sci., 5, 127-144. http://dx.doi.org/10.1098/rsos.181124.

Nakata H.M. 1963. Effect of $\mathrm{pH}$ on intermediates produced during growth and sporulation of $\mathrm{Ba}$ cillus cereus. J. Bacteriol., 86, 577-581.
Olivares J., Bedmar E. and Sanjuán J. 2013. Biological Nitrogen Fixation in the Context of Global Change. Molecular Plant-Microbe Interactions: MPMI 26, 486-494.

Page A.L. 1982. "Methods of Soil Analysis". Part I. Physical properties and Part II. Chemical and microbiological properties ( $2^{\text {nd }}$ Ed.). Amer. Soc. Agron. In Soil Sci. Soc. Amer. Inc. Madison Wisconsin, USA, 151 p.

Pereyra G., Hartmann H., Michalzik B., Ziegler W. and Trumbore S. 2015. Influence of Rhizobia Inoculation on Biomass Gain and Tissue Nitrogen Content of Leucaena leucocephala Seedlingsunder Drought. Forests. 6, 36863703.

Plackett R.L. and Burman J.P. 1946. "The Design of Optimum Multifactorial Experiments". Biometrika. 33, 305-325.

Pozo C., Toledo M.V.M., Rodelas B. and Lopez J.G. 2002. Effects of culture conditions on the production of polyhydroxyalkanoates by Azotobacter chroococcum $\mathrm{H} 23$ in media containing a high concentration of alpechin (wastewater from olive oil mills) as primary carbon source. J. Biotechnol., 97, 125-131.

Ramadas N., Singh S., Soccol C. and Pandev A. 2009. Polyhydroxybutyrate Production using Agro-industrial Residue as Substrate by Bacillus sphaericus NCIM 5149. Braz. Arch. Biol. Technol., 52, 17-23.

Rodriguez-Contreras A., Koller M., de Sousa Dias M.M., Cala-fell M., Braunegg G. and Marques-Calvo M.S. 2013. Novel poly [(R)-3hydroxybutyrate]- producing bacterium isolated from a Bolivian hypersaline lake. Food Technol. Biotechnol., 51(1), 123-130.

Sangkharak K. and Prasertsan P. 2007. Nutrient optimization for production of polyhydroxybutyrate from halotolerant photosynthetic bacteria cultivated under aerobic-dark condition. Microb. Biotechnol., 11, 1-12.

DOI: 10.2225/vol11-Issue 3-fulltext-2

Sankar S., More S.V. and Laxman R.S. 2010. Recovery of silver from waste X-ray film by alkaline protease from Conidibolus coronatus. J. Sci. Eng. Technol., 6, 60-69.

Snedecor G.W. and Cochran W.G. 1967. "Statistical Methods". Univ. Press lowa State, USA., $189 \mathrm{p}$.

Somasegaran P. and Hoben H.J. 1994. "Handbook for Rhizobia: Methods in Legume Rhizobium Technology", Springer-Verlag, New York, USA., 450 p. 
Tamdogan N. and Sidal U. 2011. Investigation of Poly- $\beta$-Hydroxybutyrate (PHB) Production by Bacillus subtilis ATCC 6633 under different conditions. Kafkas Univ. Vet. Fak. Derg., 17, 173-176.

Tharanathan R.N. and Mahadevamma S. 2003. Grain legumes, a boon to human nutrition. Trends Food Sci. Technol., 14, 507-551.

Vincent J.M. 1970. A manual for the practical study of root nodule bacteria. In: IBP Handbook No. 15, Black Well Scientific Publications, Oxford, $164 \mathrm{p}$.
Vinnere O., Fatehi J., Wright S.A. and Gerhardson B. 2002. The causal agent of anthracnose of Rhododendron in Sweden and Latvia. Mycol. Res., 106(1), 60-69.

Youseifa S.H., Abd El-Megeeda F.H., Ageezb A., Cockingc E.C. and Saleh S.A. 2014. Phylogenetic multilocus sequence analysis of native rhizobia nodulating faba bean (Vicia faba L.) in Egypt. Syst. Appl. Microbiol., 37, 560-569.

Yüksekdağ Z.N., Beyatı ı. and Aslım B. 2003. Determination of poly- $\beta$-hydroxybutyrate $(\mathrm{PHB})$ production by some mesophilic and thermophilic lactic acid bacteria. Turk. J. Biol., 27, 37-42. 
مجلة اتحاد الجامعات العربية للعلوم الزراعية ، جامعة عين شمس ، القاهرة ، مصر

مجلا(27)، عدد(2)، 1397-1383، 2019

Website: http://ajs.journals.ekb.eg

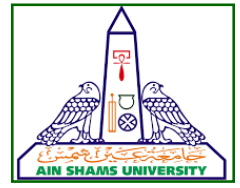

1397

Rhizobium تعظيم إنتاجية البولي بيتا هيدركسي بيوتيرات بواسطة سلالة مصرية من fabae

[114]

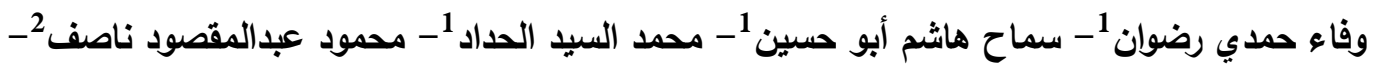

$$
\text { شوقي محمود سليم } 1
$$

1-قسم الميكروبيولوجيا الزراعية- كلية الزراعة- جامعة عين شمس- ص.ب. 68 - حدائق شبرا 11241 القاهرة- مصر

2- معهد بحوث الأراضي والمياه والبيئة - مركز البحوث الزراعية- الجيزة- مصر

*Corresponding author: wafaahamdy57@yahoo.com

Received 9 June, 2019

Accepted 23 June, 2019

كربون (مانيتول وسكروز) ومصادر نيتروجين مثل ونائل

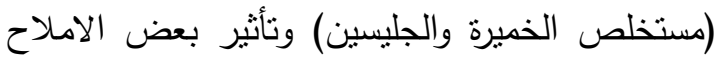

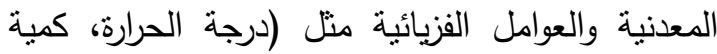

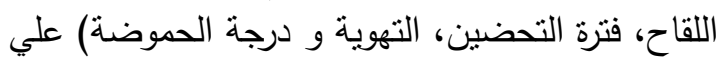
نمو الميكروب وتراكم البوليمر داخل الخلايا البكترية.

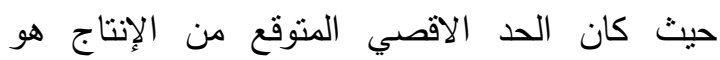
حيث أظهرت منهجية أستجابة السطح RSM كنهج احصائي إنها كفاءة وفعالة لتحسين إنتاج PHB بواسة Rhizobium fabae.

الكلمات الدالة: رايزوبيم، الفول البلدي، عزل، إنتاج،

تحسين إنتاجية، PSM PHB الأة

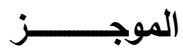

يهذف العمل الحالي الي الحصول علي عزلات من

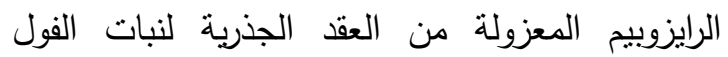
البلدي ثم إختبار نموها وإنتاجها لمركب البولي بيتا لهنيا

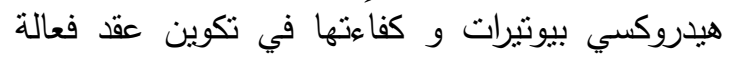

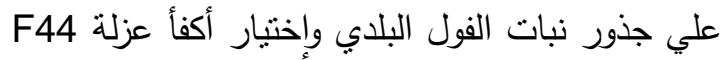

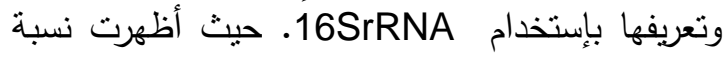

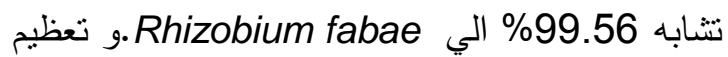

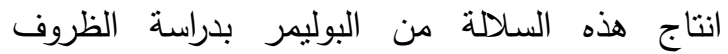
المشجعة والتي تثؤثر علي تراكم البوليمر داخل الخلايا

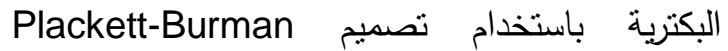
ودراسة ناثير كلاً من العوامل الغذائية من مصادر 